\title{
Synchronous volvulus of the cecum and sigmoid colon: a rare cause of intestinal obstruction
}

\author{
Vólvulo sincrónico de ciego y sigmoides: Una causa rara de obstrucción intestinal
}

Ana Rivera García-Granados* and Leopoldo E. Castañeda-Martínez

General Surgery Service, ABC Medical Center, Mexico City, Mexico

\begin{abstract}
A 102-year-old female with a past medical history of sigmoid volvulus resolved by colonoscopy a year ago presents to the emergency department with sigmoid volvulus, which is resolved by colonoscopy and rectal tube placement. Three days later, she presented abdominal distention and recurrence of the volvulus, for which a surgical resolution was decided. Laparotomy was performed, where sigmoid and cecal volvulus was found. A cecal detorsion and a cecopexy were performed, and an extended left hemicolectomy with a terminal colostomy to treat the sigmoid volvulus. The patient presents an adequate postoperative period and is discharged. Three months later, the patient was in good clinical condition, eating normally without complications. Volvulus refers to the torsion of a segment of the gastrointestinal tract. The most common sites for colonic volvulus are sigmoid and cecum; however, it is infrequent for these to occur together. We only found six cases reported in the literature of synchronous volvulus of the cecum and sigmoid colon. None of the cases was the diagnosis made preoperatively, suggesting a difficult diagnosis. Treatment depends on the patient's condition; in most reported cases, a subtotal colectomy was performed. The prognosis depends on prompt surgical intervention.
\end{abstract}

Key words: Sigmoid volvulus. Cecal volvulus. Synchronous.

\section{Resumen}

Se reporta un caso de una femenina de 102 años de edad, con antecedente de vólvulo sigmoideo resuelto por medio de colonoscopia hace un año. Se presenta al servicio de urgencias con vólvulo sigmoideo, el cual se resuelve por medio de colonoscopia y se coloca un tubo rectal. Tres días después, presenta nuevamente distensión y recurrencia del vólvulo, por lo cual se decide resolución quirúrgica. Durante la cirugía se encuentra un vólvulo sigmoideo, así como cecal. Se realiza una detorsión con cecopexia y hemicolectomía izquierda con colostomía terminal. La paciente presenta adecuada evolución. Sin complicaciones tres meses después. Vólvulo se refiere a la torsión de un segmento del tracto gastrointestinal. Los sitios más comunes de vólvulos colónicos son sigmoides y ciego, sin embargo, es extremadamente raro que estos se presenten juntos. Únicamente encontramos seis casos reportados en la literatura de vólvulo sincronico sigmoideo y cecal. En ninguno de los casos, se hizo el diagnóstico preoperatoriamente, lo que sugiere un diagnóstico complicado. El tratamiento depende del estado del paciente; en la mayoría de los casos reportados, se realizó una colectomía subtotal. El pronóstico depende de la intervención quirúrgica oportuna.

Palabras clave: Vólvulo sigmoides. Vólvulo cecal. Sincronico.

\section{Correspondence:}

*Ana Rivera García-Granados

Avda. de las Fuentes, 170

Jardines del Pedregal C.P. 01900 ,

Date of reception: 16-01-2021

Cir Cir. 2021;89(S2):4-8

Álvaro Obregon, Mexico City, Mexico

Date of acceptance: 01-03-2021

Contents available at PubMed

E-mail: arivera.gg@gmail.com

DOI: $10.24875 / C I R U .21000044$

www.cirugiaycirujanos.com

0009-7411/@ 2021 Academia Mexicana de Cirugía. Published by Permanyer. This is an open access article under the terms of the CC BY-NC-ND license (http://creativecommons.org/licenses/by-nc-nd/4.0/). 


\section{Introduction}

Volvulus refers to the torsion of a segment of the intestinal tract; this often leads to intestinal obstruction and vascular compromise of the affected segment. The most common sites of volvulus are the sigmoid colon and cecum. In the United States, sigmoid volvulus is more common in men older than 70 years old, and it represents less than $10 \%$ of intestinal obstruction. ${ }^{1,2}$ In Mexico, there is a predominance of female sex. $^{3}$

Colonic volvulus is more common in some areas of the world; these areas are known as the "Volvulus belt" including Middle East, India, South America, Afri$\mathrm{ca}$, and Russia. In the Andean area, sigmoid volvulus represents more than $50 \%$ of all intestinal obstruction. ${ }^{4}$ Andean Dolichomegacolon, an acquired condition that causes Andean people who live at an altitude of $3,000 \mathrm{~m}$ over sea level to have larger and thicker colon than usual, predisposing this population to coIonic volvulus. Also, a fiber-rich diet causes gas formation and distension of the colon, contributing to an elevated incidence of colonic volvulus. ${ }^{5}$

Colonic volvulus can lead to vascular compromise of the affected bowel segment, leading to septic shock and death. The diagnosis and treatment should be made promptly to avoid such complications.

Synchronic colonic volvulus of the cecum and sigmoid represent a diagnostic and treatment challenge. Only 7 cases, including this one, have been reported in the literature. It is essential to compare the diagnosis, management and different outcomes in these cases.

\section{Case Report}

102 year- old female, with a past medical history of chronic constipation and sigmoid volvulus one year ago, with a colonoscopic resolution, presented to our institution with a two-day history of abdominal distension, asthenia, adynamia, and poor appetite. Afterward, she developed intermittent abdominal pain and an inability to pass flatus. Examination revealed a woman in mild painful distress-normal vital signs, with moderate dehydration. The abdomen's inspection revealed a markedly distended abdomen, augmented peristalsis, with mild tenderness to palpation on the left side, without guarding or rebound tenderness. No abnormal laboratory values were found. An x-ray of the abdomen revealed sigmoid volvulus, with dilation of up

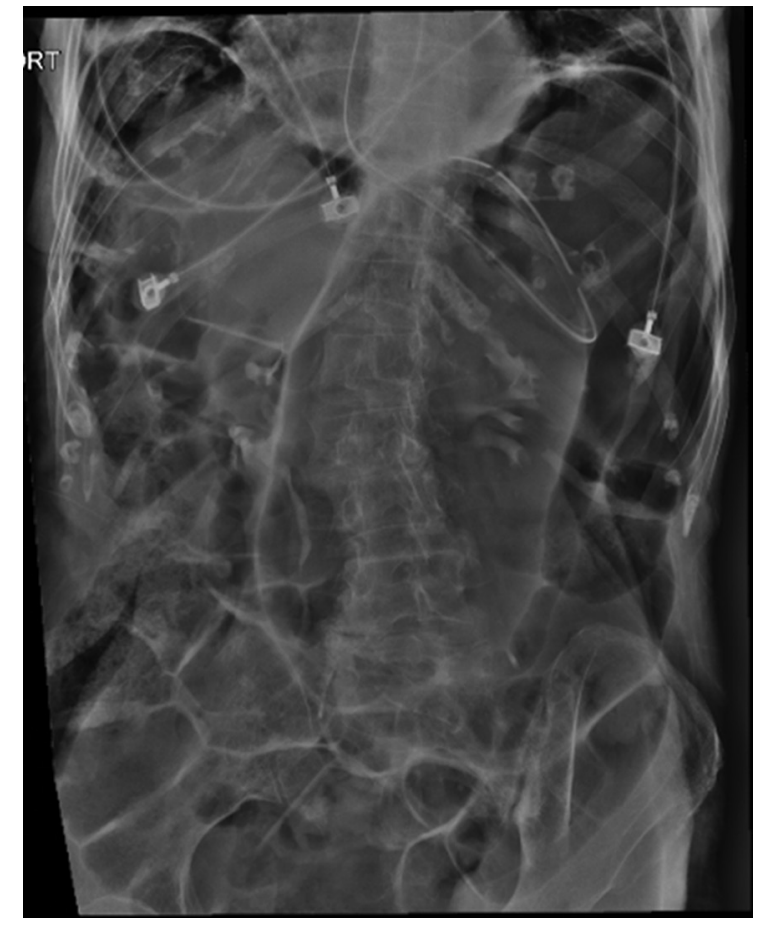

Figure 1. Abdominal x-ray demonstrating dilated loops of large bowel. Coffee-bean sign.

to $10 \mathrm{~cm}$ (Fig. 1). A nasogastric tube was placed, resuscitation and colonoscopic decompression with rectal tube placement was performed without complications. No mucosal patching was seen on colonoscopy.

The patient presented clinical and radiographic improvement, with decreased abdominal distention. $\mathrm{Pa}$ renteral nutrition and liquids were started. On her third day after colonic decompression, she presented abdominal distension, with little tolerance to enteral nutrition and leukocytosis of $14,700 \mathrm{U} / \mathrm{L}$; a CT scan revealed persistence of sigmoid volvulus, with free fluid and indirect data of vascular compromise (Fig. 2). Laparotomy was performed, where sigmoid and cecal volvulus was found, with no evidence of cecal vascular compromise (Fig. 3). A cecal detorsion and a cecopexy were performed, and an extended left hemicolectomy with a terminal colostomy to treat the sigmoid volvulus. Given the patients' malnourished state, added to an acute inflammatory state, no anastomosis was attempted. The postoperative period was uneventful, and the patient was discharged on postoperative day 9 . She returned to the hospital with abdominal distension and no output from the colostomy. No radiological evidence of bowel obstruction was found. The diagnosis of acute colonic pseudo-obstruction was made; she was treated with neostigmine 


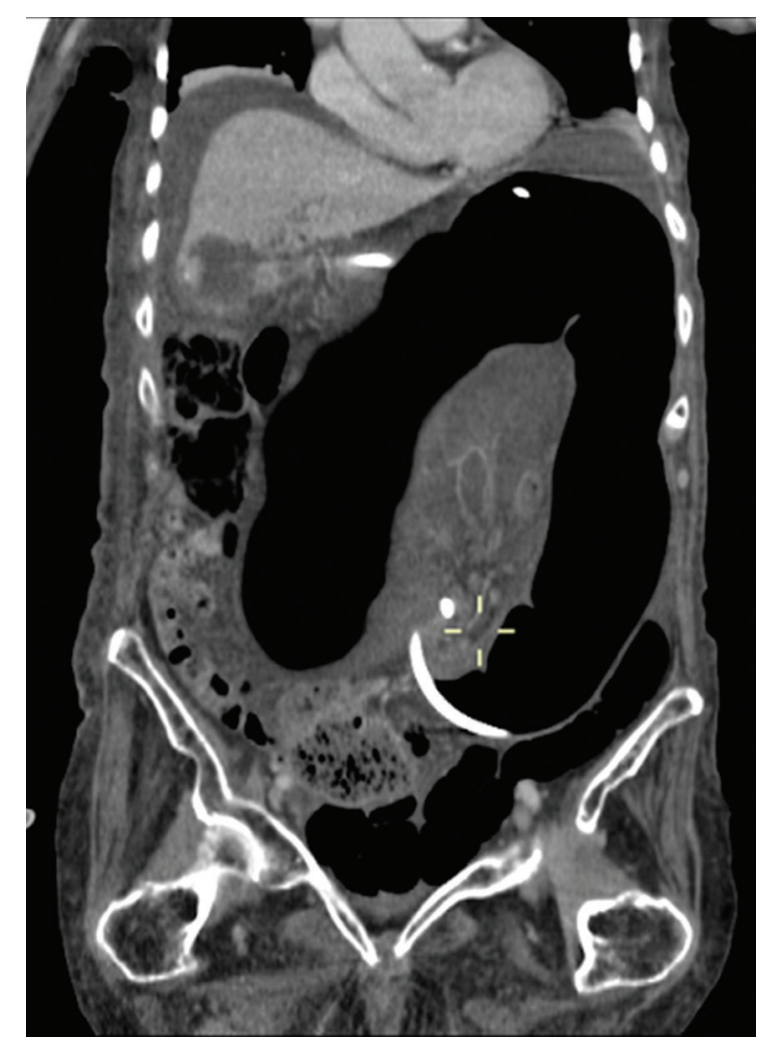

Figure 2. CT scan of the abdomen showing dilated sigmoid colon of up to $11.4 \mathrm{~cm}$ and whirl sign.

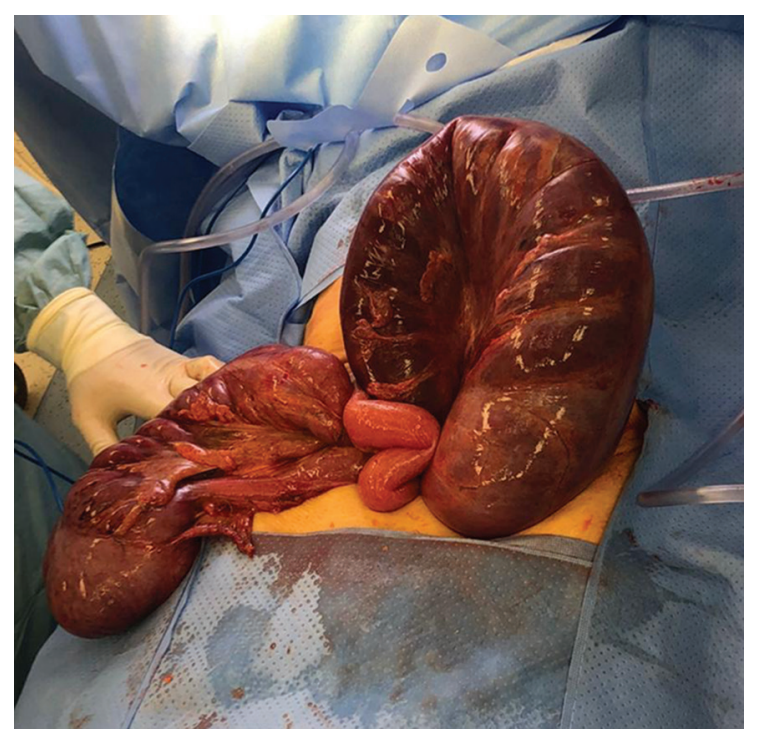

Figure 3. Intraoperative photography showing cecal and sigmoid volvulus.

and was discharged eleven days later. Three months later, the patient was in good clinical condition, eating normally without any complication.

\section{Discussion}

The most common site of colonic volvulus is the sigmoid colon, followed by the cecum. Sigmoid volvulus is more frequent in the sixth to eighth decades of life; it is mostly associated with chronic diseases, neuropsychiatric disorders, and constipation. It is two times more common in men than in women. This pathology generally presents with insidious onset of progressive abdominal pain, nausea, abdominal distension, and constipation. ${ }^{6}$ It may not be as apparent in older adults, who will generally present mild symptoms. ${ }^{7}$ The diagnosis is usually established with imaging. On abdominal radiographs, the typical findings include the presence of a u-shaped, distended sigmoid colon, customarily known as the coffee-bean sign. On abdominal CT scan, diagnostic findings of sigmoid volvulus include whirl pattern, caused by dilated sigmoid colon around its mesocolon, and birdbeak appearance caused by progressive narrowing of colon around torsion point. ${ }^{8}$

Treatment depends on the clinical status of the patient. If the patient is stable and there is no clinical suspicion of bowel necrosis or perforation, a rigid or flexible colonoscopic detorsion should be performed. This allows for the evaluation of the viability of the sigmoid colon. This is effective in $60-95 \%$ of patients ${ }^{6}$, but various studies have demonstrated a recurrence rate of up to $48 \%$ in 5 months. ${ }^{9,10}$ The definitive treatment is always surgical. Sigmoidecotmy with primary anastomosis offers better results than non-resective surgical treatment. ${ }^{6}$

Cecal volvulus is responsible for $1-3 \%$ of bowel obstruction. It is more common in younger patients than sigmoid volvulus, generally presenting in patients $35-50$ years-old. The incidence is estimated at 2.8 to 7.1 per million people per year. It is also more common in women than in men. ${ }^{11}$ In Mexico, it represents $21 \%$ of colonic volvulus. ${ }^{3}$ There are three cecal volvulus types; type I is a clockwise axial torsion along its long axis, the cecum remains in the right lower quadrant. In type II, there is torsion of the cecum and the last portion of the terminal ileum, counterclockwise, related to ectopic location, usually in the left upper quadrant. Type III, also known as cecal bascule, is an upward folding of the cecum; this is more common in young women, and it does not cause a vascular compromise in most cases. ${ }^{11}$

Treatment of cecal volvulus is always surgical. Non surgical reduction is only successful in less than $4 \%$ of the patients; plus, it is known that it increases the 
Table 1. Synchronous volvulus of the cecum and sigmoid colon

\begin{tabular}{|c|c|c|c|c|c|c|}
\hline Author & Age & Gender & Preoperative diagnosis & $\begin{array}{l}\text { Preoperative } \\
\text { treatment }\end{array}$ & Surgery & Complication \\
\hline Moore et al. ${ }^{13}$ & 62 & Male & $\begin{array}{l}\text { Bowel obstruction- cecal } \\
\text { volvulus }\end{array}$ & NG Tube & $\begin{array}{l}\text { Subtotal colectomy + } \\
\text { Ileorectal anastomosis }\end{array}$ & No \\
\hline Roy et al. ${ }^{14}$ & 77 & Male & Sigmoid volvulus & $\begin{array}{l}\text { Colonoscopy }+ \\
\text { rectal tube }\end{array}$ & $\begin{array}{l}\text { Subtotal colectomy + } \\
\text { terminal ileostomy }\end{array}$ & death \\
\hline Isalm et al. ${ }^{15}$ & 80 & Male & Chilaiditis syndrome & - & $\begin{array}{l}\text { Subtotal colectomy }+ \\
\text { ileorectal anastomosis }\end{array}$ & $\begin{array}{l}\text { Anastomosis leak - } \\
\text { terminal ileostomy }\end{array}$ \\
\hline Singh et al. ${ }^{16}$ & 60 & Male & Bowel obstruction & - & Detorsion + cecostomy & No \\
\hline Berg et al. ${ }^{17}$ & 69 & Male & Sigmoid volvulus & - & $\begin{array}{l}\text { Subtotal colectomy + } \\
\text { terminal ileostomy }\end{array}$ & - \\
\hline Elsharif et al. ${ }^{18}$ & 62 & Male & $\begin{array}{l}\text { Stomach, cecal and sigmoid } \\
\text { volvulus + situs inversus }\end{array}$ & & & Death \\
\hline
\end{tabular}

NG: nasogastric

Table 2. Synchronous volvulus of GI tract

\begin{tabular}{|c|c|c|c|c|c|c|}
\hline Author & Age & Gender & $\begin{array}{l}\text { Preoperative } \\
\text { diagnosis }\end{array}$ & Involved segments & Surgery & Complication \\
\hline Chittal et al. ${ }^{19}$ & 71 & Female & Sigmoid volvulus & $\begin{array}{l}\text { Sigmoid colon + } \\
\text { Gallbladder }\end{array}$ & $\begin{array}{l}\text { Cholecystectomy + sigmoidectomy + } \\
\text { colorectal anastomosis }\end{array}$ & Postoperative AMI \\
\hline Motsumi et al. ${ }^{20}$ & 26 & male & Sigmoid volvulus & $\begin{array}{l}\text { Sigmoid and transverse } \\
\text { colon }\end{array}$ & eSubtotal colectomy + colostomy & No \\
\hline Islam et al. ${ }^{21}$ & 56 & Female & $\begin{array}{l}\text { Internal hernia vs. } \\
\text { tumor }\end{array}$ & $\begin{array}{l}\text { Cecum and splenic } \\
\text { angle }\end{array}$ & $\begin{array}{l}\text { Subtotal colectomy + ileocolonic } \\
\text { anastomosis }\end{array}$ & No \\
\hline Lianos et al. ${ }^{22}$ & 81 & Female & Bowel obstruction & $\begin{array}{l}\text { Sigmoid and transverse } \\
\text { colon }\end{array}$ & eSubtotal colectomy + terminal ileostomy & No \\
\hline Rivera $^{23}$ & 33 & Female & $\begin{array}{l}\text { Recurrent sigmoid } \\
\text { volvulus }\end{array}$ & $\begin{array}{l}\text { Distal ileum + Sigmoid } \\
\text { colon }\end{array}$ & $\begin{array}{l}\text { lleal resection + anastomosis + Hartman } \\
\text { procedure }\end{array}$ & No \\
\hline Ndong et al. ${ }^{24}$ & 74 & Male & \multicolumn{3}{|c|}{$\begin{array}{l}\text { Bowel obstruction } \\
\text { Sigmoid and transverse colon } \\
\text { Left hemicolectomy + Loop colostomy }\end{array}$} & No \\
\hline
\end{tabular}

AMl: acute myocardial infarction

risk of perforation; bowel ischemia can go unnoticed in $25 \%$ of the patients. ${ }^{2}{ }^{12}$ Surgical treatment depends on hemodynamic stability and bowel compromise. If the bowel is compromised, the volvulus should not be untwisted to avoid reperfusion injury. ${ }^{2}$ An ileocolic resection or right hemicolectomy should be performed, with or without anastomosis. If there is no bowel compromise, then a detorsion can be performed, followed by resection or cecopexy. ${ }^{13} \mathrm{~A}$ cecopexy should only be done if a resection cannot be tolerated, for it has a high morbidity and mortality rate, with up to $14 \%$ recurrence. ${ }^{14}$

Synchronous volvulus of the cecum and sigmoid colon is an infrequent entity; to the best of our knowledge, only six cases have been reported in the literatura (Table 1) ${ }^{15-20}$, this one being the seventh. In none of the patients was the diagnosis made preoperatively. The majority of them had a preoperative diagnosis of sigmoid volvulus. ${ }^{16,19,20}$ While in one case, the preoperative diagnosis was Chilaiditis syndrome. ${ }^{17}$ All of the patients were male, and the average age was 68.3 years. Detorsion and cecostomy were performed on only one patient. ${ }^{18} \mathrm{~A}$ subtotal colectomy was performed in the rest of the patients. Two of the patients $(40 \%)$ died. ${ }^{16,20}$ The patient in which a cecostomy was performed was reported stable nine months later. ${ }^{18}$

Multiple cases of synchronous volvulus of other parts of the gastrointestinal tract have been reported (Table 2). ${ }^{21-25}$ Most of them included the sigmoid 
colon 21, 22, 24, 25, 26, and another organ, including the gallbladder ${ }^{21}$, transverse colon ${ }^{22,24,26}$, and terminal ileum ${ }^{25}$, while another presented with cecal and splenic angle volvulus. ${ }^{23} \mathrm{~A}$ subtotal colectomy was performed in those patients, that the volvulus was in two segments of the colon ${ }^{22-24}$, while segmental resection was performed in the others. ${ }^{21,} 25,26$

The synchronous volvulus of the colon is an unusual pathology that can be easily missed. The diagnosis is almost always done surgically, and the treatment varies according to the location and hemodynamic stability. Prompt surgical intervention determines the prognosis.

\section{Funding}

The authors received no specific funding for this work.

\section{Conflicts of interest}

The authors declare that does not exist any conflicts of interest.

\section{Ethical disclosures}

Protection of human and animal subjects. The authors declare that no experiments were performed on humans or animals for this study.

Confidentiality of data. The authors declare that they have followed the protocols of their work center on the publication of patient data.

Right to privacy and informed consent. The authors have obtained the written informed consent of the patients or subjects mentioned in the article. The corresponding author is in possession of this document.

\section{References}

1. Ballantyne GH, Brandner MD, Beart RW Jr, Ilstrup DM. Volvulus of the colon. Incidence and mortality. Ann Surg. 1985 Jul;202(1):83-92. doi: 10.1097/00000658-198507000-00014. PMID: 4015215; PMCID: PMC1250842.

2. Halabi WJ, Jafari MD, Kang CY, Nguyen VQ, Carmichael JC, Mills $S$, Pigazzi A, Stamos MJ. Colonic volvulus in the United States: trends, outcomes, and predictors of mortality. Ann Surg. 2014 Feb;259(2):293301. doi: 10.1097/SLA.0b013e31828c88ac. PMID: 23511842.

3. Remes-Troche JM, Pérez-Martínez C, Rembis V, Arch Ferrer J, Ayala González M, Takahashi T. Tratamiento quirúrgico del vólvulus colónico. Experiencia de 10 años en el Instituto Nacional de la Nutrición Salvador Zubirán [Surgical treatment of colonic volvulus. 10-year experience at the Instituto Nacional de la Nutrición Salvador Zubirán]. Rev Gastroenterol Mex. 1997 Oct-Dec;62(4):276-80. Spanish. Erratum in: Rev Gastroenterol Mex 1998 Jul-Sep;63(3):158. PMID: 9528296.
4. Le CK, Nahirniak P, Qaja E. Cecal Volvulus. 2020 Dec 7. In: StatPearls [Internet]. Treasure Island (FL): StatPearls Publishing; 2020 Jan-. PMID: 29262030.

5. Frisancho O. Dolicomegacolon Andino y vólvulos intestinales de altura [Dolichomegacolon of the Andes and intestinal volvulus due to altitude]. Rev Gastroenterol Peru. 2008 Jul-Sep;28(3):248-57. Spanish. PMID: 18958141.

6. Vogel JD, Feingold DL, Stewart DB, Turner JS, Boutros M, Chun J, Steele SR. Clinical Practice Guidelines for Colon Volvulus and Acute Colonic Pseudo-Obstruction. Dis Colon Rectum. 2016 Jul;59(7):589-600. doi: 10.1097/DCR.0000000000000602. PMID: 27270510.

7. Avots-Avotins KV, Waugh DE. Colon volvulus and the geriatric patient. Surg Clin North Am. 1982 Apr;62(2):249-60. doi: 10.1016/s00396109(16)42684-8. PMID: 7071692.

8. Ibáñez Sanz L, Borruel Nacenta S, Cano Alonso R, Díez Martínez P, Navallas Irujo M. Vólvulos del tracto gastrointestinal. Diagnóstico y correlación entre radiología simple y tomografía computarizada multidetector [Gastrointestinal tract volvulus: diagnosis and correlation between plain-film X-ray and multidetector computed tomography findings]. Radiologia. 2015 Jan-Feb;57(1):35-43. Spanish. doi: 10.1016/j. rx.2013.09.008. Epub 2014 Apr 4. PMID: 24703987.

9. Yassaie O, Thompson-Fawcett M, Rossaak J. Management of sigmoid volvulus: is early surgery justifiable? ANZ J Surg. 2013 Jan;83(1-2):74-8. doi: 10.1111/j.1445-2197.2012.06182.x. Epub 2012 Aug 24. PMID: 22924840.

10. lida T, Nakagaki S, Satoh S, Shimizu H, Kaneto H, Nakase H. Clinical outcomes of sigmoid colon volvulus: identification of the factors associated with successful endoscopic detorsion. Intest Res. 2017 Apr;15(2):215220. doi: 10.5217/ir.2017.15.2.215. Epub 2017 Apr 27. PMID: 28522952; PMCID: PMC5430014.

11. Gingold D, Murrell Z. Management of colonic volvulus. Clin Colon Rectal Surg. 2012 Dec;25(4):236-44. doi: 10.1055/s-0032-1329535. PMID: 24294126; PMCID: PMC3577612.

12. Madiba TE, Thomson SR. The management of cecal volvulus. Dis Colon Rectum. 2002 Feb;45(2):264-7. doi: 10.1007/s10350-004-6158-4. PMID: 11852342.

13. Majeski J. Operative therapy for cecal volvulus combining resection with colopexy. Am J Surg. 2005 Feb;189(2):211-3. doi: 10.1016/j.amjsurg.2004.11.004. PMID: 15720993.

14. Shoop SA, Sackier JM. Laparoscopic cecopexy for cecal volvulus. Case report and a review of the literature. Surg Endosc. 1993 SepOct;7(5):450-4. doi: 10.1007/BF00311742. PMID: 8211629.

15. Moore JH, Cintron JR, Duarte B, Espinosa G, Abcarian H. Synchronous cecal and sigmoid volvulus. Report of a case. Dis Colon Rectum. 1992 Aug;35(8):803-5. doi: 10.1007/BF02050333. PMID: 1644007.

16. Roy SP, Tay YK, Kozman D. Very rare case of synchronous volvulus of the sigmoid colon and caecum causing large-bowel obstruction. BMJ Case Rep. 2019 Jan 28;12(1):bcr-2018-227375. doi: 10.1136/bcr-2018227375. PMID: 30696645; PMCID: PMC6350728.

17. Islam S, Hosein D, Bheem V, Dan D. Synchronous volvulus of the sigmoid colon and caecum, a very rare cause of large bowel obstruction. BMJ Case Rep. 2016 Oct 14;2016:bcr2016217116. doi: 10.1136/bcr2016-217116. PMID: 27742643; PMCID: PMC5073715.

18. Singh G, Gupta SK, Gupta S. Simultaneous occurrence of sigmoid and cecal volvulus. Dis Colon Rectum. 1985 Feb;28(2):115-6. doi: 10.1007/ BF02552660. PMID: 3971804.

19. Berg AK, Perdawood SK. Samtidig volvulus i sigmoideum og caecum [Synchronous sigmoideum- and caecum volvulus]. Ugeskr Laeger. 2015 Sep 21;177(39):V04150346. Danish. PMID: 26418638.

20. Elsharif M, Basu I, Phillips D. A case of triple volvulus. Ann R Coll Surg Engl. 2012 Mar;94(2):e62-4. doi: 10.1308/003588412X1317122150078. PMID: 22391352; PMCID: PMC5827238.

21. Chittal R, Harris D, Patel A, Goodyear S, Parkianathan V. An interesting rare case of double volvulus. BMJ Case Rep. 2011 Feb 23;2011:bcr102010346. doi: 10.1136/bcr.10.2010.3464. PMID: 22707549; PMCID: PMC3062870.

22. Motsumi MJ, Tlhomelang $O$. Synchronous volvulus of the sigmoid and transverse colon in a 26-year-old male. J Surg Case Rep. 2018 Nov 13;2018(11 ):rjy295. doi: 10.1093/jscr/rjy295. PMID: 30443313; PMCID: PMC6232284.

23. Islam S, Hosein D, Harnarayan P, Naraynsingh V. Synchronic volvulus of splenic flexure and caecum: a very rare cause of large bowel obstruction. BMJ Case Rep. 2016 Jan 18;2016:bcr2015213029. doi: 10.1136/ bcr-2015-213029. PMID: 26783008; PMCID: PMC4735276.

24. Lianos G, Ignatiadou E, Lianou E, Anastasiadi Z, Fatouros M. Simultaneous volvulus of the transverse and sigmoid colon: case report. G Chir. 2012 Oct;33(10):324-6. PMID: 23095560.

25. Rivera-Nava JC. Simultaneous volvulus of the ileum and sigmoid colon. Rev Gastroenterol Mex. 2015 Jan-Mar;80(1):115-6. English, Spanish. doi: 10.1016/j.rgmx.2014.10.006. Epub 2015 Feb 12. PMID: 25683722.

26. Ndong A, Diao ML, Tendeng JN, Diallo AC, Ma Nyemb PM, Konaté I. Synchronous sigmoid and transverse volvulus: A case report and qualitative systematic review. Int J Surg Case Rep. 2020;75:297-301. doi: 10.1016/j.ijscr.2020.09.027. Epub 2020 Sep 10. PMID: 32979829; PMCID: PMC7519238. 